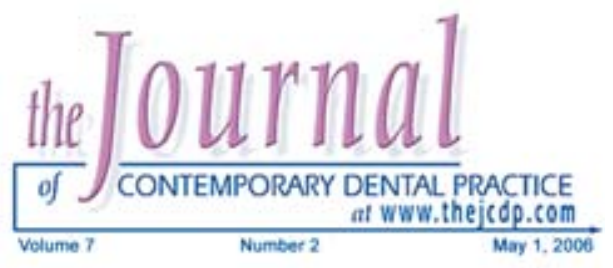

\title{
Bond Strength of Total-Etch Dentin Adhesive Systems on Peripheral and Central Dentinal Tissue: A Microtensile Bond Strength Test
}

\section{Yessilyurt, DDS, PhD; B. Bulucu, DDS, PhD}

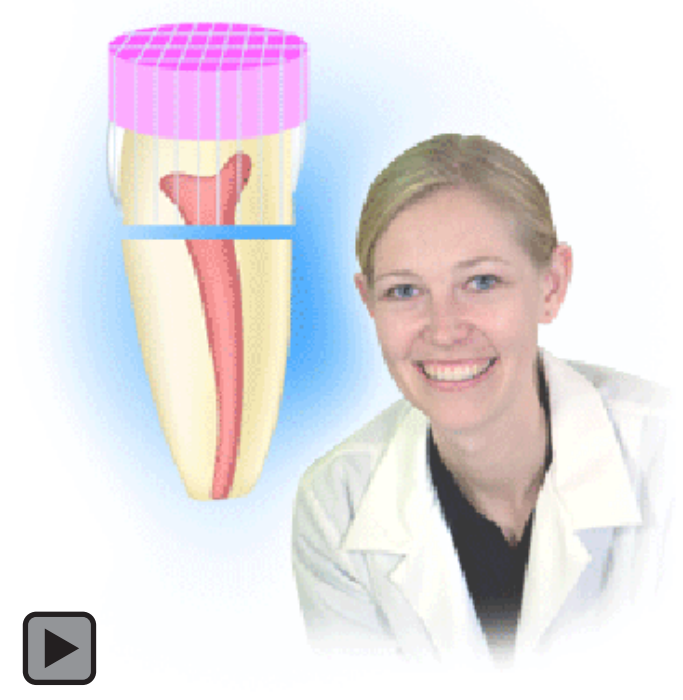

Abstract

Objective: The purpose of this study was to evaluate the microtensile bond strength ( $\mu$ TBS) of four total-etch adhesives [Excite (EB), Prime \& Bond NT (PBNT), Single Bond (SB), and One Coat Bond (OCB)] by comparing them to five self-etching adhesives (Clearfil SE Bond (CSEB), Xeno III (X III), Prompt L-Pop (PLP), AQ Bond (AQB), and Tyrian/One Step plus (TOSP)] at different dentinal areas. In addition the interface between the adhesive resins and dentin was examined using scanning electron microscopy (SEM).

Methods and Materials: Superficial occlusal dentin of extracted human molars was exposed and finished with wet 800-grit silicon carbide paper. A block of composite resin was then bonded to the molar samples with the above adhesives according to the manufacturers' instructions. After 24 hours in water at $37^{\circ} \mathrm{C}$, the specimens were sectioned into $1 \mathrm{~mm}$ thick slices and divided into two regional subgroups according to their relationship to pulp tissue using visual criteria: pulp center and pulp periphery. The slices were then trimmed for the microtensile bond test and subjected to a tensile force and crosshead speed of $1 \mathrm{~mm} / \mathrm{min}$. Two-way analysis of variance was performed for statistical analyses. In addition the bond strengths for nine adhesive systems for each dentinal area were compared using the Post-Hoc test. The resin-dentin interfaces for each adhesive system were observed under a SEM.

(C) Seer Publishing 
Results: Mean $\mu$ TBS ranged from (25.2 MPa) for TOSP to (48.9 MPa) for PBNT. The bond strengths of total-etch adhesive systems were not significantly different, and were higher than self-etch adhesive systems, except for CSEB $(p<0.05)$. No significant regional difference was observed for all of the nine adhesive systems $(p>0.05)$. SEM observation showed there is not a standard hybridization for adhesive systems.

Conclusion: Different dentinal areas may not exhibit as great an influence on bond strengths using new adhesive systems.

Keywords: Adhesive systems, dentin area, microtensile test

Citation: Yeşilyurt C, Bulucu B. Bond Strength of Total-Etch and Self-Etch Dentin Adhesive Systems on Peripheral and Central Dentinal Tissue: A Microtensile Bond Strength Test. J Contemp Dent Pract 2006 May;(7)2:026-036.

\section{Introduction}

A durable interfacial adhesion between tooth and biomaterial is essential for an ideal restoration. Enamel bonding has shown tremendous clinical success; however, dentin bonding cannot be predictably relied upon for long-term interfacial integrity. Dentin has a complex biological structure. Marshall et al. stated the various structural components and properties of dentin could directly affect the adhesive bond. ${ }^{2}$

Adhesive systems bonding strength values to dentin may change due to the location of the bonding area. Water content and permeability of dentin is not identical for all regions because of variations in the number of tubules per $\mathrm{mm}^{2}$ Pashley reported tubule number density and peritubuler dentin area decreases with distance from the pulp, and intertubuler dentin area increases with distance from the pulp. ${ }^{3}$

The problem of poor bonding to dentin near the pulp is due to the high content of water. ${ }^{4}$ Regional variations in dentinal structure and composition is related to other factors besides depth. Regional variation is reflected in the permeability characteristics at different locations within a tooth. For example, the permeability of occlusal dentin is higher over the pulp horns than at the center of the occlusal surface. ${ }^{5}$ Similarly, proximal dentin is more permeable than occlusal dentin, and coronal dentin is more permeable than root dentin. ${ }^{6}$ However, the early generation of adhesive systems were less hydrophilic and, thus, more sensitive to the higher intrinsic wetness of dentin. ${ }^{\prime}$

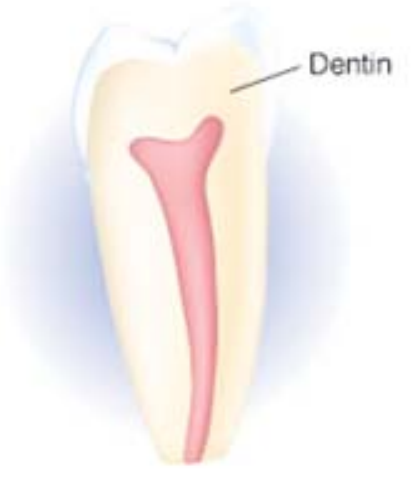

Modern adhesives can be grouped into two categories according to their etching technique: total-etch and self-etch products. ${ }^{8}$, Total-etch systems have shown high bond strength to dentin. Self-etch systems have been produced as an alternative to total-etch systems. A selfetch system contains a simultaneously acidic and hydrophilic monomer and does not need to be rinsed away after etching. Effective demineralization provides sufficient adhesive penetration into enamel and dentin. ${ }^{9}$

Newer adhesive systems produce relatively high bond strengths to moist or dry dentin, with complete or partial removal of the smear layer. ${ }^{10}$ However, bond strength can vary according to intrinsic wetness, region, and adhesive system. ${ }^{11}$

However, there are very few extensive studies about self-etch systems, and their clinical use is disputed. Since one-step self-etch systems' properties have not been largely studied, they have not yet been proven effective by the scientific community. ${ }^{12,13}$ 
Studies about adhesive systems aim to provide well qualified and long lasting adhesion, practical application, and decrease of the working time in order to decrease the technical sensitivity of the adhesive. ${ }^{14}$ Clinicians prefer materials with an easy application technique when performing adhesive dentistry in daily practice; therefore, all of these simplified products are usually accepted with enthusiasm by clinicians. ${ }^{15}$

Adhesive dentistry has advanced greatly over the last decade. The bonding of resin composite to enamel and possibly dentin seems to be sufficient for clinical success. A clinical trial is the most valid way to evaluate the quality and efficacy of adhesive systems. However, long-term clinical trials are difficult to perform because they take a long time. ${ }^{15}$ Bond strength measurement in a laboratory test is one of the most effective methods of characterizing commercial dentin bonding products. ${ }^{16,17}$

Using a microtensile test it is possible to evaluate the adhesive systems bonding strength at different regions. Sano et al. developed a microtensile bond test method using very small surface areas. This test method can measure regional bond strength. ${ }^{18}$

The purpose of this study was to evaluate the microtensile bond strength ( $\mu$ TBS) of four totaletch adhesives by comparing them with five selfetching adhesives at the different dentinal areas. In addition the interface between the adhesive resins and dentin was examined using scanning electron microscopy (SEM).

\section{Methods and Materials}

The nine adhesive systems used in the study, their manufacturers, and bonding procedures are shown in Table 1. Dentin adhesive systems were divided into two groups:

Group I: Total-etch Adhesives: Excite (EB), Prime \& Bond NT (PBNT), Single Bond (SB), and One Coat Bond (OCB)

Group II: Self-etch Adhesives: Clearfil SE Bond (CSEB), Xeno III (X III), Prompt L-Pop (PLP), AQ Bond (AQB), and Tyrian/ One Step plus (TOSP)

\section{Specimen Preparation}

Seventy-two extracted non-carious human mandibular third molars were used as specimens in this study. The specimens were stored in $0.9 \%$ $\mathrm{NaCl}$ solution (normal saline) and $0.05 \%$ sodium azide at $4-7^{\circ} \mathrm{C}$ until use. The storage period did not exceed three months. Just prior to the preparation, a tooth specimen was thoroughly rinsed with running water and excess tissue was removed.

\section{Bonding Procedure and Microtensile Bond Strength ( $\mu$ TBS)}

The specimen teeth were randomly divided into nine groups and allocated to one of the nine adhesive systems listed in Table 1. A specimen tooth was then mounted in an Isomet low-speed bone saw (No. 11-4244; Buehler Ltd., Lake Bluff, IL, USA) with a $4 \times 0.012$ in $^{2}$ diamond-rim blade (No. 11-4244; Buehler) and sectioned perpendicular to its long axis for creating a flat dentin surface. All of the occlusal enamel was removed.

A standard smear layer was created using water cooled sand papers (silicone carbide), grits 200400-600, consecutively, for 10 seconds each, rotating the teeth $90^{\circ}$, and finally using a 800 grit for 60 seconds.

The dentin surface was thoroughly rinsed with water, and the selected adhesive systems were then applied to the tooth according to each manufacturer's directions (Table 1).

Using the adhesive procedures recommended by the manufacturer, a resin block using TPH Spectrum (Dentsply/Caulk, USA) was fabricated using a layer technique in the occlusal direction up to a final height of $4 \mathrm{~mm}$. Each layer was light cured for 40 seconds using a LUNAR curing light, with $750 \mathrm{~W} / \mathrm{cm}^{2}$ light intensity (LUNAR, Benlioğlu Inc, TURKEY) (Figure 1).

Roots were cut off at their middle third using a diamond disc. All specimens were stored in distilled water at $37^{\circ} \mathrm{C}$ for 24 hours. They were then cut along the $z$ and $y$ axis, perpendicular to the longitudinal tooth axis using a diamond disc under water irrigation, (non-trimming technique) 
Table 1. Manufacturers' guidelines for each adhesive system tested in this study.

\begin{tabular}{|c|c|c|c|c|}
\hline $\begin{array}{l}\text { Adeziv } \\
\text { Systems }\end{array}$ & Acid-etch & Adhesive Resin & $\begin{array}{l}\text { Applleation } \\
\text { Mathods }\end{array}$ & $\begin{array}{l}\text { Manufacturer } \\
\text { Firm }\end{array}$ \\
\hline $\begin{array}{l}\text { Prime \& Bond } \\
\text { NT (PBNT) }\end{array}$ & $\begin{array}{c}34 \% \\
\text { Phosphoric acid }\end{array}$ & $\begin{array}{l}\text { PENTA, UDMA, acetone, nano-filler, } \\
\text { Cetyaminehydrofluoride, initiators, } \\
\text { stabilizer }\end{array}$ & $\begin{array}{l}\text { a }(15 \mathrm{sec}) \mathrm{bc} \\
\text { ef }(20 \mathrm{sec}) \\
\mathrm{g} f(40 \mathrm{sec})\end{array}$ & $\begin{array}{l}\text { DentsplyiCaulk, } \\
\text { Milford, U.S.A }\end{array}$ \\
\hline $\begin{array}{l}\text { Single Bond } \\
\text { (SB) }\end{array}$ & $\begin{array}{c}37 \% \\
\text { Phosphoric acid }\end{array}$ & $\begin{array}{l}\text { Bis-GMA,HEMAwater-ethanol, } \\
\text { polyalkenoaic acid copolymer, } \\
\text { dimethacrylate, amine, photoinitator }\end{array}$ & $\begin{array}{l}\text { a }(15 \mathrm{sec}) \mathrm{bc} \\
\mathrm{e} f(10 \mathrm{sec}) \\
\mathrm{g} f(40 \mathrm{sec})\end{array}$ & $\begin{array}{l}\text { 3M ESPE } \\
\text { ST.Paul, Minn }\end{array}$ \\
\hline Excite (EB) & $\begin{array}{c}37 \% \\
\text { Phosphoric acid }\end{array}$ & $\begin{array}{l}\text { Fosfonat akrilat monomer, HEMA, } \\
\text { nano doldurucu etanol }\end{array}$ & $\begin{array}{l}\text { a }(15 \text { sec }) \text { b c } \\
\text { ef }(20 \text { sec }) \\
g f(40 \mathrm{sec})\end{array}$ & $\begin{array}{l}\text { Ivoclar Nivadent } \\
\text { Amherst, NY }\end{array}$ \\
\hline $\begin{array}{l}\text { One Coat Bond } \\
\text { (OCB) }\end{array}$ & $\begin{array}{c}34 \% \\
\text { Phosphoric acid }\end{array}$ & $\begin{array}{l}\text { HEMA, HPMA, MMA, UDMAWater } \\
\text { based, glyceromethacrylate, } \\
\text { amorph silicid acid }\end{array}$ & $\begin{array}{l}\text { a }(15 \mathrm{sec}) \mathrm{bc} \\
\text { e } \mathrm{f}(30 \mathrm{sec}) \\
g \mathrm{f}(40 \mathrm{sec})\end{array}$ & $\begin{array}{l}\text { Coltene/Accord } \\
\text { Switzerland }\end{array}$ \\
\hline $\begin{array}{l}\text { Clearfil SE } \\
\text { Bond (CSEB) }\end{array}$ & $\begin{array}{c}\text { MDP,HEMA, } \\
\text { hydrophilic } \\
\text { dimethacrylate, } \\
\text { camphorquinone, } \\
\text { water }\end{array}$ & $\begin{array}{l}\text { MDP,Bis-GMA,HEMA, hydrophilic } \\
\text { dimethacrylate, camphorquinone }\end{array}$ & $\begin{array}{l}d(20 \mathrm{sec}) \\
\mathrm{ce} \\
\mathrm{cf}(10 \mathrm{sec}) \\
g f(40 \mathrm{sec})\end{array}$ & $\begin{array}{l}\text { Kuraray Medical } \\
\text { J.Morita/Japan }\end{array}$ \\
\hline Xeno III (X III) & \multicolumn{2}{|c|}{$\begin{array}{l}\text { Liquid A: HEMA, water/Ethanol, BHT, stabilizer, nano- } \\
\text { filler } \\
\text { Liquid B: PEM-F, UDMA, camphorquinone, EPD }\end{array}$} & $\begin{array}{l}\text { de (mix) } 5 \mathrm{sec} \\
\text { de }(20 \mathrm{sec}) \\
\mathrm{cf}(10 \mathrm{sec}) \\
g f(40 \mathrm{sec})\end{array}$ & $\begin{array}{l}\text { Dentsply! } \\
\text { Germany }\end{array}$ \\
\hline $\begin{array}{l}\text { Tyrian/One } \\
\text { Step Plus } \\
\text { (TOSP) }\end{array}$ & Tyrian SPE & Bis-GMA, HEMA, acetone & $\begin{array}{c}\text { Tyrian(15sec) } \\
\text { e c }(20 \mathrm{sec}) \\
g \mathrm{f}(40 \mathrm{sec})\end{array}$ & $\begin{array}{c}\text { Bisco } \\
\text { Schaumburg/ } \\
\text { U.S.A }\end{array}$ \\
\hline $\begin{array}{l}\text { Prompt L-Pop } \\
\text { (PLP) }\end{array}$ & \multicolumn{2}{|c|}{$\begin{array}{l}\text { Phosphoric ester methacrylate, methacrylate, flour, } \\
\text { initiators, stabilizer, water }\end{array}$} & $\begin{array}{l}\text { e }(15 \mathrm{sec}) \\
\mathrm{cf}(10 \mathrm{sec}) \\
\mathrm{g} f(40 \mathrm{sec})\end{array}$ & $\begin{array}{c}\text { 3M/ESPE AG } \\
\text { Seefeld- } \\
\text { Germany }\end{array}$ \\
\hline$A Q$ Bond (AQB) & \multicolumn{2}{|c|}{ UDMA and 4-META, acetone/water based } & $\begin{array}{c}\text { e }(30 \text { sec }) \\
c(3-5 \text { sec }) \\
f(10 \text { sec }) \\
g f(40 \text { sec })\end{array}$ & $\begin{array}{l}\text { Sun Medical } \\
\text { Japan }\end{array}$ \\
\hline
\end{tabular}

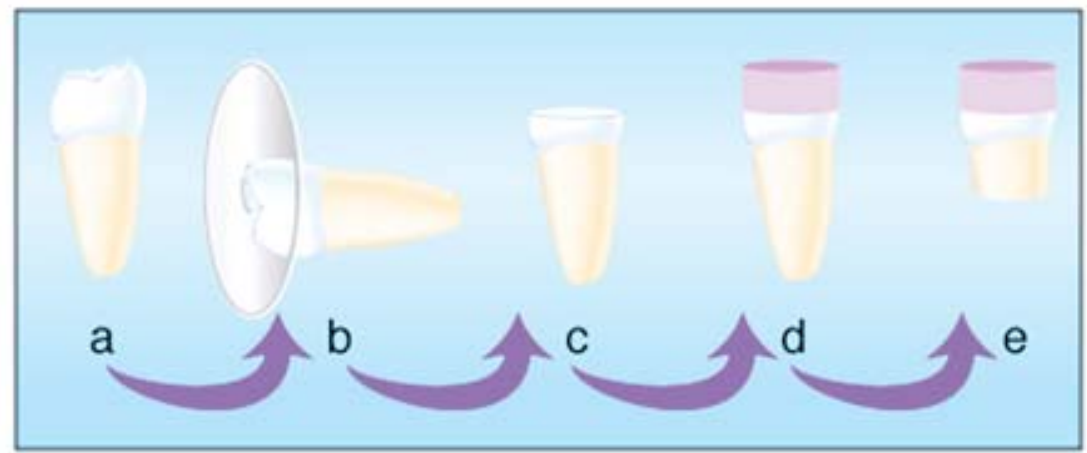

Figure 1. Schematic diagram of the specimen preparation for the microtensile bond test (a. Non-caries tooth, $\mathbf{b}$-c. Preparation of a flat dentin surface for bonding. d. Incremental resin composite buildup. e. Tooth roots were removed with a diamond disk.) 
to obtain stick shape specimens with $1 \pm 0.2 \mathrm{~mm}^{2}$ of bonding area. No failures occurred during specimen production.

From each tooth, 10-15 sticks were prepared; for each adhesive system, approximately 80 samples of sticks were obtained. The sticks were kept moist during preparation for the microtensile test (maximum 20 minutes).

To determine the adhesive systems regional bonding values, the slices were then divided into the following two regional subgroups by visual criteria (Figure 2):

- The central region located between the pulp horns (central)

- The peripheral region located between the pulp horns and DEJ (periphery)

Calipers (Mitutoyo, China) with a precision of 0.01 $\mathrm{mm}$ were used to measure the bonded areas of the specimens. Both ends of the specimens were glued to testing devices using cyanoacrylate adhesive (ZAPIT, DVA, Corona, CA, USA).

A Universal Testing machine (Dillon, Tronix Inc., 1000 Instron Drive, Fairmont, MN 56031, USA) was used to conduct $\mu$ TBS tests at a crosshead speed at $1 \mathrm{~mm} / \mathrm{min}$. Results were transformed in Mega Pascal (MPa).

The mean bond strengths (MPa) of each adhesive system were compared using one way analysis of variance and the least significant difference (LCD) multiple comparison test $(p<0.05)$.

\section{SEM Observations}

Two samples were observed for each adhesive system. After preparation of the dentin surface, adhesive materials were applied according to the manufacturer's directions. Composite resin was placed for $1 \mathrm{~mm}$ thickness and polymerized. Roots were removed under the enamel cement junction and teeth were sectioned vertically by a diamond bur. Samples were embedded in an epoxy resin for 24 hours and stored in 10\% formalin solution. The samples were hand polished with 600,800,1000, and 1200-grit SIC paper followed by diamond pastes $(6 \mu \mathrm{m}, 3 \mu \mathrm{m}$, $1 \mu \mathrm{m}$, and $0.25 \mu \mathrm{m}$ ) (Streuers, Copenhagen, Denmark).

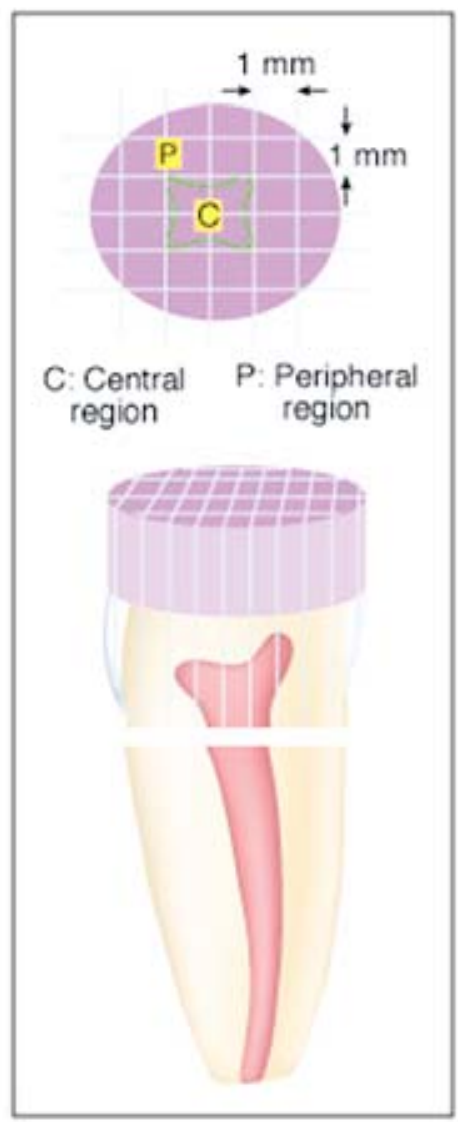

Figure 2. Central and peripheral region locations relative to the pulp chamber.

Samples were cleaned in an ultrasonic cleaner for 10 minutes. Specimens were subjected to $10 \%$ phosphoric acid for 10 seconds, then a $5 \%$ sodium hypochlorite for 5 minutes, and then the specimens were washed by distilled water and dried at room temperature before SEM observation. After this, they were dehydrated in increasing concentrations of ethanol to $100 \%$, critical point dried, fractured across the bonded interfaces, and gold sputter-coated with Polaron Sc500 Sputter Coater device (VG Microtech Inc. England). The structure of the bonded interface SEM (JSM-5600, JEOL Ltd, Tokyo, Japan) was investigated. Photomicrographs of a representative area of the surface were taken between 1000x and 4000x magnification.

\section{Statistics}

Statistical analysis was accomplished using the SPSS (10.0, Chicago, IL, USA) statistical software program. The mean and standard deviation of 


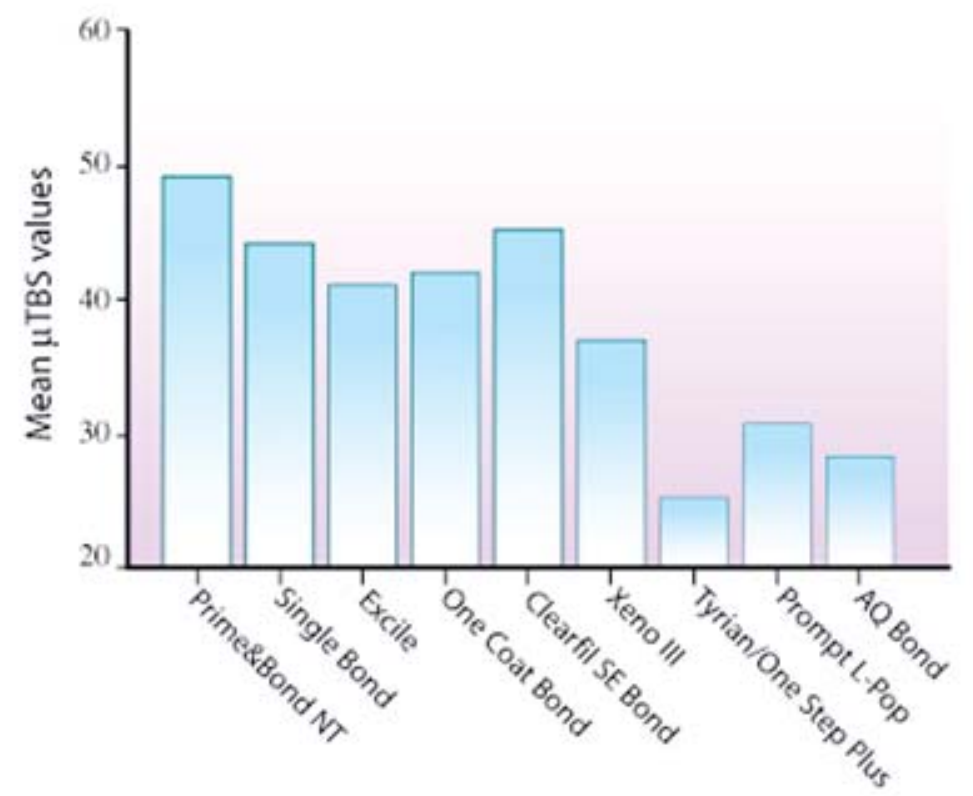

Figure 3. Mean bond strength results of nine adhesive systems (MPa).

the tensile bond strengths were calculated for each group. The bond strengths for two dentinal areas for each adhesive system were compared using two-way analysis of variance, and then to compare the mean differences the Post Hoc test was used.

The Mann Whitney $U$ test was used to the abnormal prevalence of two comparison properties. The percentage of failure types for adhesive materials Chi-square analysis importance test was used.

\section{Results}

The medium values obtained with microtensile test of the nine adhesive systems tested can be seen on Figure 3 , in an increasing order of bond strength.

The mean $\mu$ TBS, standard deviations, and minimum and maximum values for each adhesive system are given in Table 2.

Group I: PBNT (48.8MPa) $\mu$ TBS value was found higher than SB (44.4MPa), OCB (41.9MPa), and EB (41.1MPa ). However, there was no statistical difference among all total-etch system's bonding strength values $(P>0.05)$.

Group II: CSEB (45 MPa)'s $\mu$ TBS value was found to be statistically different $(p<0.05)$ than other self-etch adhesive systems [X III (37 MPa), PLP (30.7 MPa), AQB (28 MPa), and TOSP (25.2 MPa)].

Comparing all groups, total-etch systems obtained bond strength values statistically higher than self-etch systems $(p<0.05)$ but were statistically similar to the CSEB ( $p>0.05)$.

Mean $\mu$ TBS ranged from 25.2 MPa for TOSP to 48.9 MPa for PBNT.

Four different groups were observed when estimating using the TUKEY HSD of the adhesive systems multiple comparison (Table 3). TOSP, $A Q B$, and PLP showed low bonding values and were significantly different $(p<0.05)$ from other adhesive systems, but PLP showed similar behavior with XIII $(\alpha=0.05)$.

On the other hand, total-etch systems and CSEB's $\mu$ TBS values were significantly different from other adhesive systems and showed high bonding strength $(p<0.05)$. However, X III showed a common group with low and high groups $(\alpha=0.05)$ (Table 3$)$. Nine adhesive systems bonding strength at peripheral and central region is shown in Table 2.

There were no significant regional differences among adhesive systems $\mu$ TBS values ( $p>0.05$ ). 
Table 2. Mean values, standard deviation, minimum and maximum of microtensile bond strengths of the adhesives systems. (Adjustment for multiple comparisons): Bonferroni.

\begin{tabular}{|c|c|c|c|c|c|}
\hline \multicolumn{2}{|c|}{$\begin{array}{l}\text { Dentin Adhesive } \\
\text { Systems }\end{array}$} & \multirow{2}{*}{$\begin{array}{c}\text { Location of } \\
\text { bonding } \\
\text { area }\end{array}$} & \multirow{2}{*}{$\begin{array}{c}\begin{array}{c}\text { MeantStd. } \\
\text { Error }\end{array} \\
46.4 \pm 2.7\end{array}$} & \multirow{2}{*}{$\begin{array}{c}95 \% \\
\text { confidence } \\
\text { Interval Min- } \\
\text { Max. }\end{array}$} & \multirow{2}{*}{$\begin{array}{l}\mathbf{n} \\
39\end{array}$} \\
\hline \multirow{8}{*}{$\begin{array}{l}\text { Total-etching } \\
\text { adhesives }\end{array}$} & \multirow{2}{*}{$\begin{array}{l}\text { Prime \& Bond } \\
\text { NT }\end{array}$} & & & & \\
\hline & & Peripheral & $51.7 \pm 2.9$ & $46.1 \pm 57.3$ & 35 \\
\hline & \multirow{2}{*}{ Single Bond } & Central & $45.1 \pm 2.2$ & $40.8 \pm 49.4$ & 60 \\
\hline & & Peripheral & $42.2 \pm 2.9$ & $36.6 \pm 47.8$ & 35 \\
\hline & \multirow{2}{*}{ Excite } & Central & $42.7 \pm 2.4$ & $38.1 \pm 47.3$ & 52 \\
\hline & & Peripheral & $37.9 \pm 3.3$ & $31.5 \pm 44.4$ & 26 \\
\hline & \multirow{2}{*}{ One Coat Bond } & Central & $40.4 \pm 2.3$ & $35.8 \pm 45.0$ & 52 \\
\hline & & Peripheral & $44.3 \pm 3.0$ & $38.3 \pm 50.2$ & 31 \\
\hline \multirow{10}{*}{$\begin{array}{l}\text { Self-etching } \\
\text { adhesives }\end{array}$} & \multirow{2}{*}{$\begin{array}{l}\text { Clearfil SE } \\
\text { Bond }\end{array}$} & Central & $44.7 \pm 2.5$ & $39.8 \pm 49.6$ & 46 \\
\hline & & Peripheral & $45.4 \pm 2.7$ & $40.1 \pm 50.7$ & 39 \\
\hline & \multirow{2}{*}{ Xeno III } & Central & $38.1 \pm 2.2$ & $33.8 \pm 42.5$ & 57 \\
\hline & & Peripheral & $35.3 \pm 2.8$ & $29.8 \pm 40.8$ & 36 \\
\hline & \multirow{2}{*}{$\begin{array}{l}\text { Tyrian/One } \\
\text { Step Plus }\end{array}$} & Central & $27.2 \pm 2.9$ & $25.9 \pm 37.2$ & 30 \\
\hline & & Peripheral & $23.5 \pm 2.7$ & $21.7 \pm 32.3$ & 36 \\
\hline & \multirow{2}{*}{ Prompt L-Pop } & Central & $32.3 \pm 2.6$ & $28.1 \pm 38.4$ & 41 \\
\hline & & Peripheral & $28.9 \pm 2.9$ & $23.0 \pm 34.6$ & 33 \\
\hline & \multirow{2}{*}{ AQBond } & Central & $29.0 \pm 3.0$ & $24.5 \pm 36.2$ & 31 \\
\hline & & Peripheral & $27.4 \pm 2.9$ & $23.0 \pm 34.3$ & 33 \\
\hline
\end{tabular}

TOSP (25.2 MPa) had the lowest bond strength among the adhesives tested, while those of PBNT (48.9 MPa) was the highest in the peripheral region. The highest $\mu$ TBS value at the central region belonged to $\mathrm{PBNT}, \mathrm{SB}$, and CSEB. The lowest $\mu$ TBS value belonged to TOSP. The relation of region differences and bonding strength is shown at Tables 2 and 3.

Fractured specimens were observed under a stereo microscope (SZ-PT Olympus, Japan) to determine the type of fracture after microtensile testing. Failures after testing mostly occurred between the adhesive layer and dentin (adhesive failures $83.1 \%$ ) with some specimens exhibiting mixed fractures (combined fractures between the adhesive layer and composite/dentin 1.9\%). A few specimens, showed cohesive failures in composite $(4.7 \%)$ or in dentin (10.2\%).

\section{Discussion}

The $\mu$ TBS of nine dentin adhesive systems to dentin substrate's peripheral and center regions are evaluated in this study. The hybrid layer and presence of resin tags were observed by SEM.

Many factors can influence the bonding performance of adhesive systems to dentin. Among these are the dentin substrate, the testing procedures, and the handling of the material. ${ }^{19}$ 
Table 3. Adhesive system's multiple comparison test by the Tukey HSD test.

\begin{tabular}{|c|c|c|c|c|c|c|}
\hline \multicolumn{2}{|c|}{ Tukey HSD } & n & 1 & 2 & 3 & 4 \\
\hline \multirow{9}{*}{$\begin{array}{l}\text { Dentin } \\
\text { Adhesive } \\
\text { Systems }\end{array}$} & $\begin{array}{l}\text { Tyrian/ } \\
\text { One Step } \\
\text { Plus }\end{array}$ & 66 & 25.179 & & & \\
\hline & $A Q$ bond & 64 & 28.168 & & & \\
\hline & $\begin{array}{l}\text { Prompt L- } \\
\text { Pop }\end{array}$ & 74 & 30.727 & 30.727 & & \\
\hline & Xeno III & 93 & & 37.044 & 37.044 & \\
\hline & Excite & 78 & & & 41.122 & 41.122 \\
\hline & $\begin{array}{l}\text { One Coat } \\
\text { Bond }\end{array}$ & 83 & & & 41.856 & 41.856 \\
\hline & $\begin{array}{l}\text { Single } \\
\text { Bond }\end{array}$ & 95 & & & 44.037 & 44.037 \\
\hline & $\begin{array}{l}\text { Clearfil } \\
\text { SE Bond }\end{array}$ & 85 & & & 45.002 & 45.002 \\
\hline & $\begin{array}{l}\text { Prime\& } \\
\text { Bond NT }\end{array}$ & 74 & & & & 48.913 \\
\hline
\end{tabular}

The properties of dentin are important in understanding adhesion to dentin. Current dentin bonding systems exhibit shear strength values for adhesive/dentin bonds of around $20 \mathrm{MPa}$. However, the location and orientation of the dentin is important when bond strength testing is conducted. ${ }^{20,21}$

Dentin is a vital tissue and consists of tubules and fluid in the tubules. Tubule orientation and dispersion is smooth. ${ }^{21}$ Tubule number per $\mathrm{mm}^{2}$ is not equal, so its permeability changes to the location. ${ }^{22}$ Dentin near pulp horns is more permeable than dentin further away because the density and diameter of tubules are highest near pulp horns. $^{5}$

There are a number of potential advantages for micro tensile test methodology: (1) the ability to measure regional bond strengths, (2) it permits testing of a very small area, and (3) it facilities examination of the failed bonds by SEM. ${ }^{1}$

We found no statistical difference between the central dentin and peripheral dentin in each adhesive system $(p>0.05)$. For both bonding areas, the highest bonding strength was found for
PBNT (central 46.4 MPa, peripheral 51.7 MPa); the lowest bonding strength was found for PLP (central 32.2 MPa, peripheral 28.8 MPa).

Bond strength measurements have become a well-recognized method to analyze an important part of the in vitro performance of dental adhesives and have supported the development of improved bonding systems and techniques. It has been suggested bond strengths of $17 \mathrm{MPa}$ to $20 \mathrm{MPa}$ are required to resist contraction forces sufficiently to attain gap-free margins of resin composite restorations. ${ }^{23}$

This success is gained by today's adhesive systems. But technique sensitivity and application time is still a problem. To overcome this problem new products are produced. Selfetch adhesive systems were produced as an alternative for total-etch systems to reduce the technique sensitivity and application time.

In this study the mean bonding strength of total-etch adhesives were between 41-49 $\mathrm{MPa}$. Among the tested total-etch and self-etch systems, the highest $\mu$ TBS value was observed at PBNT. There was no statistical difference 
( $p>0.05$ ) among total-etch adhesive systems bonding strength. The total-etch system's main compound and application technique similarity may cause the result.

Agostini et al. have claimed the amount of filler in an adhesive system may affect the bonding strength. An increased filler amount will reduce the polymerization shrinkage and resin dentin bonding would be more qualified. In their study among four adhesive systems CSEB's filler content is $10 \%$ higher and has shown the highest bonding strength. ${ }^{24}$

Kaaden et.al. also have indicated, compared to unfilled systems, the filled bonding agent CSEB tested in our study resulted in bond strengths to dentin higher than this type of unfilled adhesives systems PLP. ${ }^{9}$ However, it remains unclear whether the filler content is actually the reason for this difference.

PBNT, EB, CSEB, TOSP, and X III contains nano filler. Nano filler's particle dimension and quantity can differ due to the producer firm. In our study TOSP (contains filler) and PLP (does not contain filler) showed similar bonding strength ( $p>0.005)$. Also EB, PBNT (both contain filler), and OCB's (does not contain filler) bonding strength values were similar.

Excessive water content of the adhesive system may also dilute the primer and reduce its effectiveness. PLP contains $80 \%$ water, while CSEB contains $50 \%$ water. $^{9}$ Water based adhesive systems may result in lower bond strength due to incomplete polymerization of the monomers. ${ }^{25}$ CSEB has moderate acidic monomer, while PLP has more strong acidic monomer. ${ }^{26}$

Like CSEB, AQB also the dissolves smear layer but its performance is insufficient. Self-etch primer, which has weak acid, has the following mechanism: dissolves smear layer, demineralites superficial dentin, and penetrates adhesive resin. But when the smear layer is thick, the weak acid's effectiveness is not sufficient and has a limited adhesive resin penetration. This will affect the result of the bonding strength. ${ }^{27}$ Self-etching primers and adhesives, by virtue of their selfetching nature, contain acidic monomers and water. ${ }^{26}$ The effectiveness of a self-etch adhesive system depends on multiple factors.

It is proposed, after abundant application of the self-etching primer for 15 seconds, the adhesive has to be applied in two consecutive layers with a light brushing motion. The way this adhesive system is applied may guarantee a better penetration of the resin monomer; if there is a failure or lack in the first application, it can be compensated for on the second one. ${ }^{12}$

Among several factors that may interfere with the quality of bonding, the type of adhesive systems used is of great importance. Systems employing a separate acid etching step are apparently more sensitive to dentin characteristic depth than are self-etching systems. ${ }^{11}$

Also, there is an advantage related to application technique (except for CSEB); two-step and one-step self-etch systems demonstrated lower bonding strength to dentin than did total-etch systems.

In our study TOSP, AQB, and PLP are self-etch adhesives and had a low bonding strength. They were significantly different $(p<0.05)$ from other adhesive systems. PLP differed from them and showed common results with X III $(\alpha=0.05)$.

PBNT, CSEB, SB, OCB, and EB showed the highest bonding strength, and their $\mu$ TBS values were significantly different from other adhesive systems $(p<0.05)$. It is surprising that CSEB showed a higher bonding strength than other selfetch systems. This is probably due to CSEB's different acidic monomer content and high filler particle content.

In one in vitro study Bouillaguet et al. (2001) compared the dentin bonding performance of eight adhesive systems using a $\mu$ TBS test. They have found PBNT's $\mu$ TBS strength was higher than EB and PLP. EB's bonding strength was higher than PLP. ${ }^{28}$ These results are parallel with the present study but differ in there were no statistical differences ( $p>0.05)$ among PBNT and EB.

OCB is a water based adhesive system. It was expected to have a low $\mu$ TBS because of residual 
water around collagen fibrils causing insufficient monomer infiltration. However, OCB showed a high bonding value. At similar studies, low bonding values were found. ${ }^{14,29}$ Different results may be due to test techniques.

XIII and PLP have a similar application method. Both adhesive systems $\mu$ TBS were near to each other and showed lower bonding strength than to total-etch systems.

In the present study we found no regional difference among total-etch and self-etch systems. This result may due to the lack of the simulation of pulpal pressure.

Pereira et al. evaluated the bond strength of one acetone-based self-etching system to different regions of dentin (i.e., periphery, central, or pulp horn) either with or simulated pulpal pressure. They found low bonding strength values around pulp horns. Even under pulpal pressure they found no differences between the peripheral and central regions. They declared regional differences of bonding strength may be due to the property of adhesive material. ${ }^{11}$ These results are similar to our results. Dentin permeability can differ due to the dentin region and type of conditioner system.

The interface dentin-adhesive systemcomposite resin can be clearly seen in SEM photomicrographs, with hybridization and resin tags in all adhesive systems studied (Figures 4-8).

The findings of this qualitative study do not represent a hybridization standard for the adhesive system used, since other factors are also involved including the dentinal substrate and the relationship between dentinal substrate and the adhesive system. Variation of hybrid layer thickness was observed between the adhesive materials, among the specimens of the same adhesive, and in different areas of the same specimens. The hybrid layer analysis revealed different hybridization patterns, suggesting the attachment seems to be influenced by many factors and a standardization of dentinal substrate is impossible. ${ }^{30}$

It might be said the quality, rather than the quantity (thickness), of the resin-impregnated layer is of greater importance for the creation of high bond strengths to dentin. ${ }^{31,32}$

In the present study CSEB had a thin hybrid layer and a thick adhesive layer. Kaaden's study supports our result. ${ }^{9}$ Frankenberger et al. determined coating more than one layer and increasing the filler content of adhesive materials increases hybrid layer thickness. ${ }^{33}$

By SEM observation demineralized dentin by conditioner has 2-4 $\mu$ deepness of hybrid layer by a good penetration of resin to dentin tubules. Due to the adhesive material and technique, thickness of the adhesive layer was variable and ranged between 10 and $30 \mu \mathrm{m}$. It is thought high bonding strength is seen while adhesive layer's thickness increases. ${ }^{34}$ These observations support the concept of stress absorbing material in presence of thick adhesive layers ${ }^{35}$, although there is no statistical evidence available from the current study to support this concept. Adhesive layer's thickness is not equal at all surfaces. This situation is explained by the dispersion of filler in the resin. ${ }^{28}$

In contrast to this result Cho and Dickens stated $\mu$ TBS values increases while adhesive layer's thickness increases. But this increase is not statistically meaningful. ${ }^{36}$

This is especially true of the one-step selfetch systems in which the time allowed for the chemical reactions appears to be extremely shortened. This result is somewhat supported by the SEM micrographs showing poorly infiltrated smear layers. It is still unclear if a prolonged application time will increase the performance of this system. ${ }^{28}$ In our study we have found weak infiltration to tubules and low bonding strength to dentin for PLP. Low bond strengths recorded with the PLP may indicate the single component material cannot yet fulfill all requirements for the production of effective adhesive layers.

During the past 15 years there has been an enormous development in adhesive resins. Technique sensitivity and continuousness of the restoration is still a problem. Future studies must be focused on the longevity of tooth restoration wholeness and decrease the technique sensitivity. 


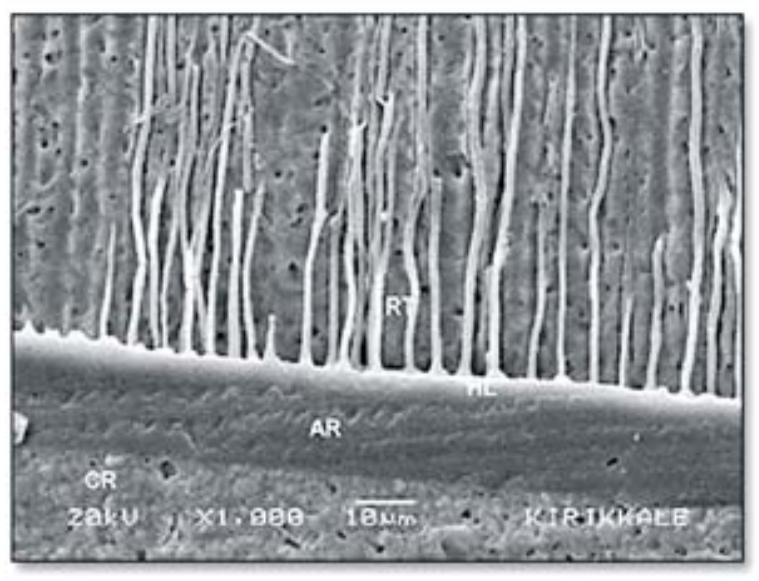

Figure 4. SEM photomicrograph of specimen bonded with Clearfil SE Bond (Resin-dentin interface). Homogeneous hybrid layer and diffuse resin tags observed (original magnification, x1000). (RT: Resin Tag, AR: Adhesive Resin, CR: Composite Resin, HL: Hybrid Layer)

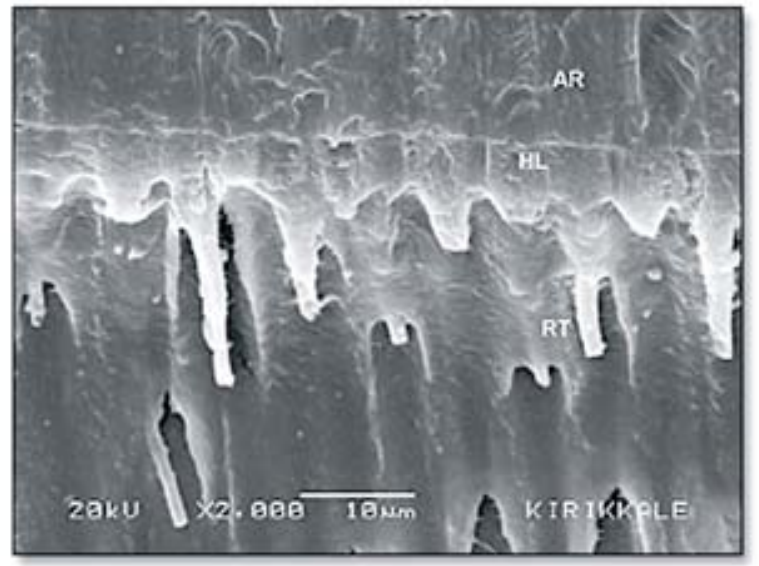

Figure 6. Prime \& Bond's resin-dentin interface by SEM micrograph. Hybrid layer is seen slightly and resin tags were not homogenous (original magnification, x2000).

(RT: Resin Tag, AR: Adhesive Resin, HL: Hybrid Layer)

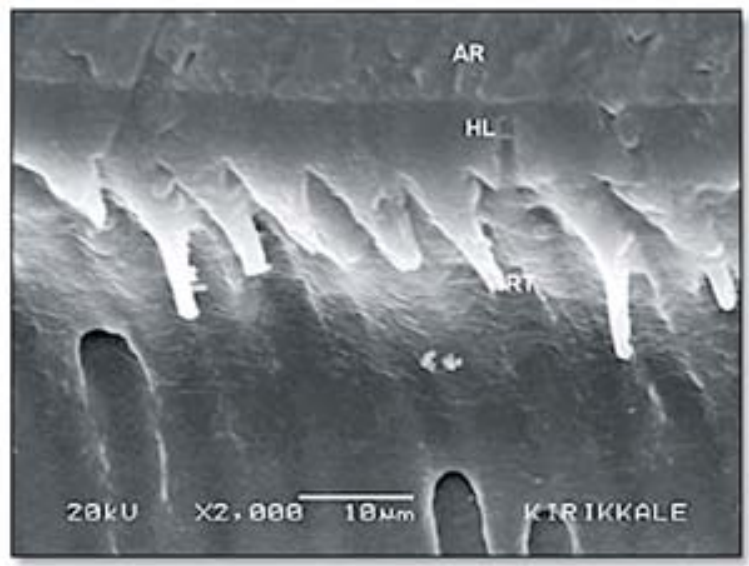

Figure 5. SEM resin-dentin interfaces formed by Excite Bond. Resin tags were shorter and irregular compared to Clearfil SE bond but hybrid layer constant (original magnification, x2000).

(RT: Resin Tag, AR: Adhesive Resin, HL: Hybrid Layer)

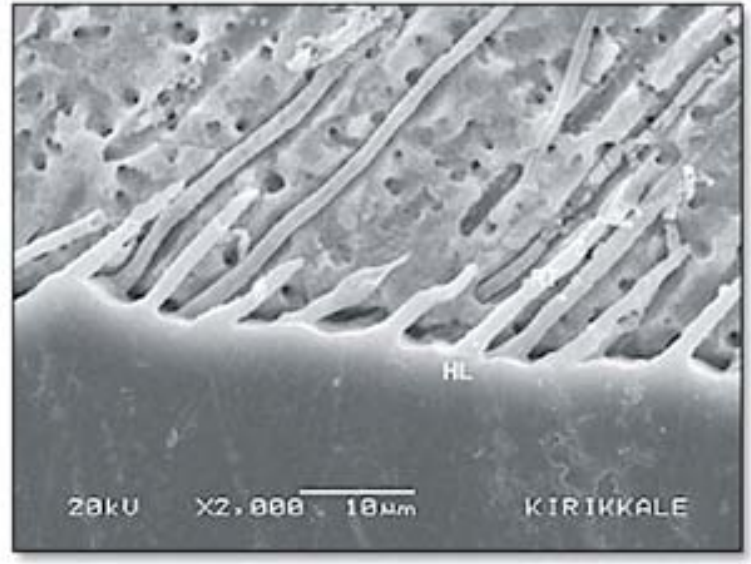

Figure 7. Prompt L-Pop's resin-dentin interface by SEM micrographs. The hybrid layer was not homogeneous and the lengths of the tags were variable (original magnification, x2000). (RT: Resin Tag, HL: Hybrid Layer)

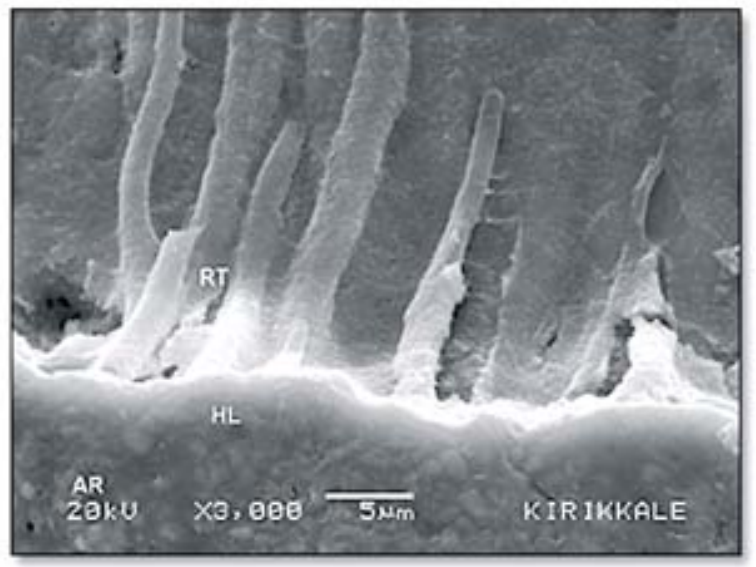

Figure 8. Xeno IIl's resin-dentin interface by SEM micrographs (original magnification, x2000).

(RT: Resin Tag, AR: Adhesive Resin, HL: Hybrid Layer) 


\section{Conclusion}

There is no significant difference among four total-etch adhesive system's bonding strength $(p>0.05)$

- Among five self-etch adhesive materials there was a statistical difference among CSEB with the other self-etch systems $(p<0.05)$.

- Comparison among total-etch and self-etch systems except CSEB, total-etch systems bonding strength was found statistically higher than other self-etch adhesive systems $(p<0.05)$. CSEB showed equal bonding strength with the other total-etch adhesives.
- Among all adhesive systems the highest $\mu$ TBS value was at PBNT, lowest value was at TOSP.

- No significant regional difference was observed for all of the nine adhesive systems $(p>0.05)$.

- SEM observation showed there is not a standard hybridization for adhesive systems. Presence of resin tags and longevity has changed due to dentin location and type of the adhesive material

\section{References}

1. Armstrong S, Boyer D, Keller J. Microtensile bond strength testing and failure analysis of two dentin adhesives. Dent Mater. 1998; 14(1):44-50.

2. Marshall GW Jr, Marshall SJ, Kinney JH, Balooch M. The dentin substrate: structure and properties related to bonding. J Dent. 1997; 25(6):441-58.

3. Pashley DH. Dentin: a dynamic substrate--a review. Scanning Microsc. 1989; 3(1):161-74.

4. Burrow MF, Nopnakeepong U, Phrukkanon SA. A comparison of microtensile bond strengths of several dentin bonding systems to primary and permanent dentin. Dent Mater. 2002; 18(3):239-45.

5. Pashley DH, Andringa HJ, Derkson GD, Derkson ME, Kalathoor SR Regional variability in the permeability of human dentine. Arch Oral Biol. 1987;32(7):519-23.

6. Pashley DH, Pashley EL. Dentin permeability and restorative dentistry: a status report for the American Journal of Dentistry. Am J Dent. 1991; 4(1):5-9.

7. Prati C, Pashley DH. Dentin wetness, permeability and thickness and bond strength of adhesive resins. Am J Dent. 1992; 5, 33-38.

8. Kanca J. Improving bond strength through acid etching of dentin and bonding to wet dentin surfaces. J Am Dent Assoc. 1992; 123(9):35-43.

9. Kaaden C, Powers JM, Friedl KH, Schmalz G. Bond strength of self-etching adhesives to dental hard tissues. Clin Oral Investig. 2002; 6(3):155-60.

10. Gwinnett AJ. Moist versus dry dentin: its effect on shear bond strength. Am J Dent. 1992; 5(3):127-9.

11. Pereira PN, Okuda M, Sano H, Yoshikawa T, Burrow MF, Tagami J. Effect of intrinsic wetness and regional difference on dentin bond strength. Dent Mater. 1999; 15(1):46-53.

12. Cardoso P, Sadek F. Microtensile bond strength on dentin using new adhesive systems with selfetching primers. Braz J Oral Sci. 2003; 2(4), 156-159.

13. Suh BI. A study of the compatibility of adhesives with composites. Proceeding from the SCO Dental Products, Inc., Symposium. 2003; 24(8), 4-9 (Suppl.).

14. Tanumiharja M, Burrow MF, Tyas MJ. Microtensile bond strengths of seven dentin adhesive systems. Dent Mater. 2000; 16(3):180-7.

15. Perdigao J, Lopes M. Dentin bonding questions for the new millennium. J Adhes Dent. 1999; 1(3):191-209.

16. Phrukkanon S, Burrow MF, Tyas MJ. The influence of cross-sectional shape and surface area on the microtensile bond test. Dent Mater. 1998; 14(3):212-21.

17. Perdigao J. Dentin bonding as a function of dentin structure. Dent Clin North Am. 2002; 46(2): 277-301 
18. Sano $\mathrm{H}$, Shono $\mathrm{T}$, Sonoda $\mathrm{H}$, et al. Relationship between surface area for adhesion and tensile bond strength evaluation of a micro-tensile bond test.Dent Mater. 1994; 10(4):236-40.

19. Bouillaguet S, Ciucchi B, Jacoby T, et al. Bonding characteristics to dentin walls of class II cavities, in vitro. Dent Mater. 2001; 17(4):316-21.

20. Watanabe LG, Marshall GW, Marshall SJ. Dentin shear strength: effects of tubule orientation and intratooth location. Dent Mater. 1996; 12(2):109-15

21. Konishi N, Watanabe LG, Hilton JF, Marshall GW, Marshall SJ, Staninec M. Dentin shear strength: effect of distance from the pulp. Dent Mater. 2002; 18(7):516-20.

22. Pashley DH, Pashley EL, Carvalho RM, Tay FR. The effects of dentin permeability on restorative dentistry. Dent Clin North Am. 2002; 46(2):211-45

23. Davidson CL, Gee AJ, Feilzer A. The competition between the composite-dentin bond strength and the polymerization contraction stress. J Dent Res. 1984; 63(12):1396-9.

24. Agostini FG, Kaaden C, Powers JM. Bond strength of self-etching primers to enamel and dentin of primary teeth. Pediatr Dent. 2001; 23(6):481-6.

25. Jacobsen T, Soderhold KJ. Some effects of water on dentin bonding. Dent Mater. 1995; 11(2):132-6.

26. Pashley DH, Tay FR. Aggressiveness of contemporary self-etching adhesives. Part II: etching effects on unground enamel. Dent Mater. 2001; 17(5):430-44.

27. Nakabayashi N, Pashley D. Hybridization of Dental Hard Tissues. Quintessence Publishing Co, Ltd. 1998.

28. Bouillaguet S, Gysi P, Wataha JC, Ciucchi B, Cattani M, Godin C, Meyer JM. Bond strength of composite to dentin using conventional, one-step, and self-etching adhesive systems.J Dent. 2001; 29(1):55-61.

29. Fritzenschaft A, Haller B. Extrusion bond strength to dentin of new self-priming adhesives. J Dent Res. 1998; 77, 638 (Abst.).

30. Macari S, Goncalves M, Nonaka T, Santos JM. Scanning electron microscopy evaluation of the interface of three adhesive systems. Braz Dent J. 2002;13(1):33-8.

31. Burrow MF, Takakura H, Nakajima M, Inai N, Tagami J, Takatsu T. The influence of age and depth of dentin on bonding. Dent Mater. 1994; 10(4):241-6.

32. Kwong SM, Cheung GS, Kei LH, Itthagarun A, Smales RJ, Tay FR, Pashley DH. Micro-tensile bond strengths to sclerotic dentin using a self-etching and a total-etching technique. Dent Mater. 2002; 18(5):359-69.

33. Frankenberger R, Perdigao J, Rosa BT, Lopes M. "No-bottle" vs "multi-bottle" dentin adhesives a microtensile bond strength and morphological study. Dent Mater. 2001;17(5):373-80.

34. Abdalla AL, Davidson CL. Shear bond strength and microleakage of new dentin bonding systems. Am J Dent. 1993; 6(6):295-8.

35. Hashimoto M, Ohno H, Endo K, Kaga M, Sano H, Oguchi H. The effect of hybrid layer thickness on bond strength: demineralized dentin zone of the hybrid layer. Dent Mater. 2000; 16(6):406-11.

36. Cho BH, Dickens S. Effects of the acetone content of single solution dentin bonding agents on the adhesive layer thickness and the microtensile bond strength. Dent Mater. 2004; 20(2):107-15. 
About the Authors

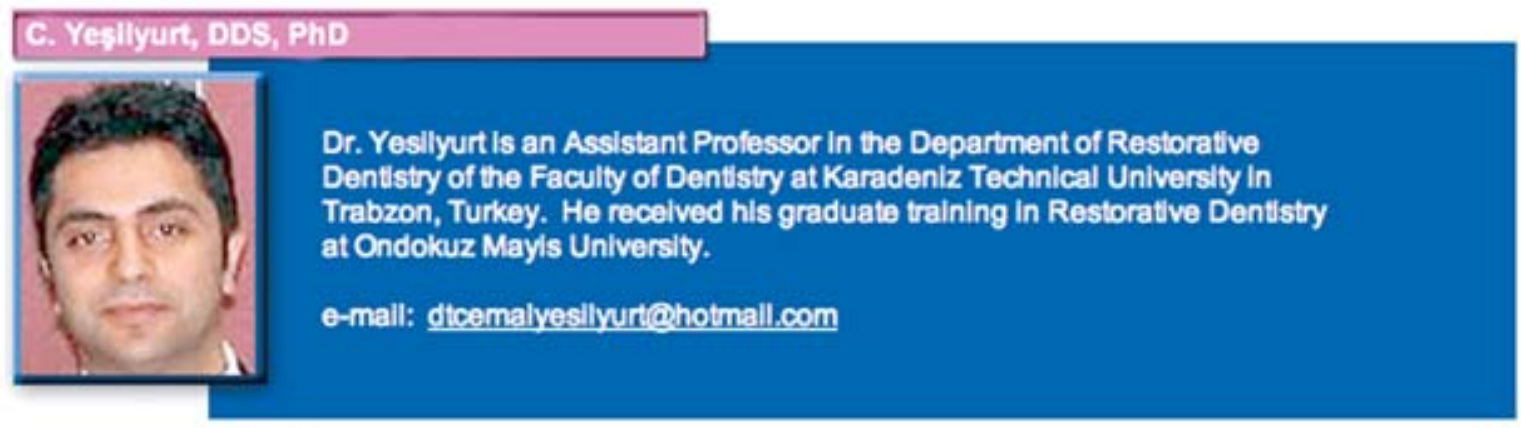

\section{B. Bulueu, DDS, PhD}

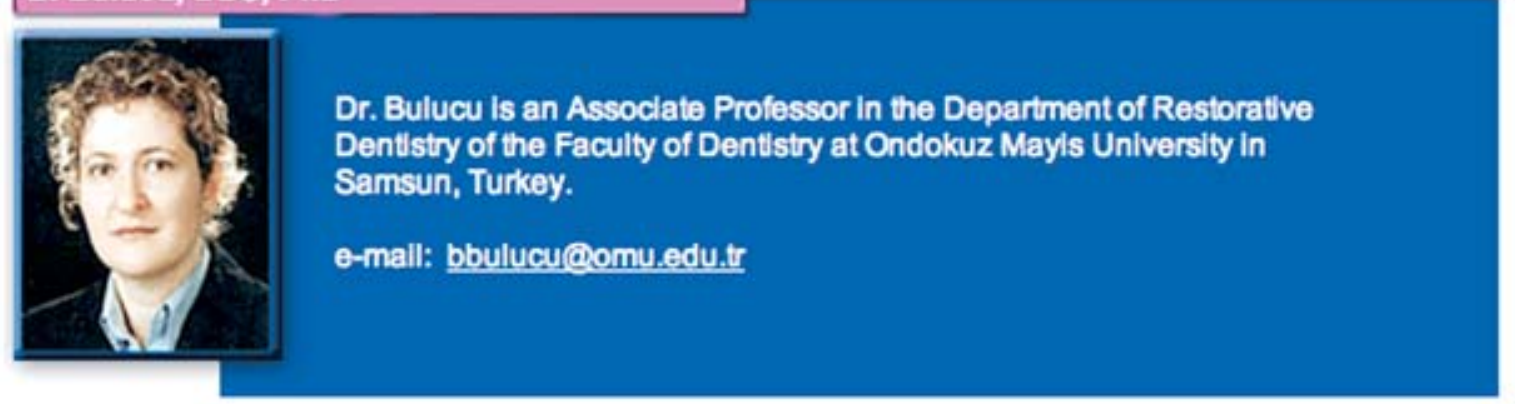

